\title{
HISTOPATHOLOGICAL STUDIES ON EPIZOOTIC ULCERATIVE SYNDROME IN SOME FISHES FROM DEMRA, DHAKA
}

\author{
Muhammad Saiful Islam, Hamida Khanum, Asma Sultana \\ Rimi Farhana Zaman and Shahela Alam \\ Parasitology Branch, Department of Zoology, Faculty of Biological Sciences \\ University of Dhaka, Dhaka-1000, Bangladesh
}

\begin{abstract}
Histopathological studies of early and late stages of Epizootic Ulcerative Syndrome infected fishes from three natural ponds at Demra, Dhaka. Five different types of freshwater wild fishes such as Anabas testudineus, Channa punctatus, Colisa fasciatus, Mystus vittatus and Puntius ticto were collected from August, 2009 to December, 2010. In this study, a prevalence of 64\% (322/500) was recorded. Channa punctatus was found to be the most infected fish among the examined fishes. Petechia haemorrhages and moderate necrosis with melanomacrophages and multinucleated giant cells without fungal hyphae were pronounced in the early stages in the muscles. Moderate to severe necrosis friable tissues possessing trailing fungal hyphae associated with fungal, protozoan and bacterial infection may have caused denuding or total erosion of the affected tissues. Extensive ulcers and high mortality were prominent in the late stages of infection. Cystic granulomas associated with multinucleated giant cells often engulfing fungal hyphae were the most characteristic features at the late stages in EUS affected fish. Other observations made were muscle degeneration, surrounding perforated muscle fibres and frequent degeneration of the blood vessel walls. However, the causative link between EUS and the observed histopathological features needs to be further elucidated.
\end{abstract}

Key words: Histopathological, epizootic ulcerative syndrome, fishes, Dhaka

\section{INTRODUCTION}

Epizootic ulcerative syndrome (EUS) has been the cause of severe losses in cultured and captured fisheries in Asia and Australia for over 25 years (Roberts et al. 1994). EUS was defined at a regional seminar in Bangkok as "a seasonal epizootic condition of freshwater and estuarine warm water fish of complex aetiology, characterized by the presence of invasive Aphanomyces infection and necrotising ulcerative lesions typically leading to a granulomatous response (ODA, 1994). It is a seasonal disease condition which usually occurs after heavy rain and during the cooler parts of the year and causes ulcerative lesion on the body or head of affected fish. Diseased fishes exhibit myonecrosis and fungal granulomas in the tissue (Prodhan et al. 2007).

In 1970, the first report of the disease was found in farmed Ayu (Plecoglossus altivelis) in Japan, where the condition was known as Mycotic Granulomatosis (MG) (Egusa 1992) and rapidly spread to many parts of the country and affected many fish species. More than 120 susceptible species have so far been recorded as being affected by EUS. EUS has affected at least 31 different species of fish in Bangladesh (Barua 1994). 
Histopathology had been a main tool in identifying EUS. Chinabut and Limsuwan (1983) described a "severe chronic granulomatous mycosis" in histological sections of lesions from diseased fish in Thailand. The causal agent were thought to be due to Achlya and Saprolegnia spp. (Pichyangkura and Bodhalamik 1983) and were dismissed as secondary agents (Tonguthai 1985).

A detailed description on the histopathology of snakeheads, C. striatus experimentally infected with pathogenic Aphanomyces at different water temperatures was given by Chinabut (1995). They recorded degenerative changes in all samples in the early stages of the disease, but inflammatory infiltrate is much more marked in fish kept at 26 and $31^{\circ} \mathrm{C}$. By 8 days of postinjection, extensive mycotic granulomatosis is observed in the muscle from fish maintained at 26 and $31^{\circ} \mathrm{C}$, while the fish kept at $19^{\circ} \mathrm{C}$ developed a severe invasive myonecrosis with limited macrophage response.In Indian major carps $100 \%$ mortality accompanied by deep lesions was found whereas in common carp, there was no mortality and severe lesions (Mohan 2002). The present study on the histopathology of early and advanced stages of EUS of selected infected fishes from Demra, Dhaka.

\section{MATERIAL AND METHODS}

Fish sampling: A total of five hundred specimens were collected from three ponds. Five different types of freshwater wild fishes were taken as sample for the study purpose. The average water temperature during this period was $25^{\circ} \mathrm{C}$. Infected fishes were Anabas testudineus, Channa punctatus, Mystus vittatus and Puntius ticto. These fishes were collected from August 2009 to December 2010. Average water temperature during that period was $25^{\circ} \mathrm{C}$. The collected fish were brought from ponds to the Parasitology Laboratory, Department of Zoology, University of Dhaka.

Preparation of histopathological slides: On arrival at the laboratory, the fishes were identified, grouped, sexed and their total lengths were measured using centimeter scale. Then the fish and was observed and ulcerated areas and lesions were identified. Sampled fish was divided into two categories : (a) early stages of infection and (b) late stages of infection.

Within 24 to 48 hours, microscopy examination and sample fixing was carried out on all collected fishes. Samples of skin, underlying muscle tissue and major internal organs were removed and fixed in 10\% neutral buffered formalin and processed for histological study in a standard manner. Slides were stained with Haematoxylin and Eosin $(\mathrm{H} \& \mathrm{E})$ and Gomoris Hexamine. In addition, samples of tissues underlying ulcers were fixed in 95\% ethanol prior to molecular examination. The ribbon of tissue was attached on the slide by means of Mayer's albumen. After deparafinization and rehydration of tissues, tissues were stained by using Haematoxylene, alcohol, ammonia and eosin (Cable 1963). 
Fixation of tissue sample: The fixed tissues were gradually dehydrated in ascending concentration of alcohol from $50 \%-100 \%$ by automatic tissue processor in Dhaka Medical College Hospital Laboratory. Then the tissue were cleared in xylene and a paraffin bath with temperature range of $60^{\circ} \mathrm{C}-70^{\circ} \mathrm{C}$ was followed after that. The tissue were treated in molten paraffin for 1-2 hours. Molten paraffin was then poured into a block of iron blocked plate. The tissues were carefully embedded in a proper plan and the plate was allowed to harden in the ice chamber of a refrigerator. After trimming the block, sections were cut at 4-5 micron in thickness (Drury and Wallington 1980 and Virgona 1992).

\section{RESULTS AND DISCUSSION}

During the period of August 2009 - December 2010, Anabas testudineus, Channa punctatus, Colisa fasciatus, Mystus vittatus and Puntius ticto were caught from different ponds in Demra (Table 1). Histopathological studies were done on 100 infected fishes in the laboratory and the progressive diagnostic symptoms of EUS were recorded. The fishes were noted to show:

- Reduced appetite,

- Swim with head out of the water,

- Floating lethargically and Death.

- Small red or grey erosions appeared at the early stage.

- Lesions expand into large ulcers, loss of scales, haemorrhages, oedema (late stage)

-Snakeheads may show severe erosion of the head or body cavity.

Histopathology: In early stages small hemorrhagic lesions on skin surface was seen without affecting underlying muscle. Early lesions continue to show mild epithelial necrosis, surrounding oedema, hemorrhage of underlying dermis and inflammatory cell infiltration, but accompanied with severe necrotizing myopathy although only a few fungal hyphae enclosed in epithelioid capsules are apparent. No disruption of internal organs.

Advanced lesions showed large bacterial ulcerations, massive necrotizing granulomatuos mycosis of underlying muscle fibres involving a distinctive branching aseptate oomycete coated with epithelioid cells. Hyphae may invade abdominal viscera and penetrate renal tubules and glomeruli causing death. Usually, only mild generalized histopathological changes in other organs.

From the Table 1, it was observed that the affected fish were three hundred and twenty two. Sampled fish was divided into two categories : (a) early stages of infection (119) and (b) late stages of infection (203). Highest infection (80\%) was found in Channa punctatus and the lowest (51\%) infected fish was Anabas testudineus. Early stage of infection was less observed in A. testudineus, only $31.37 \%$. 
Table 1. Stages of infection in the affected fish during August 2009 - December 2010.

\begin{tabular}{|c|c|c|c|c|c|c|c|}
\hline \multirow[b]{2}{*}{ Name of species } & \multicolumn{3}{|c|}{ Total number of fish } & \multirow{2}{*}{$\begin{array}{l}\text { Early } \\
\text { stage }\end{array}$} & \multirow{2}{*}{$\begin{array}{c}\text { Percen- } \\
\text { tages } \\
(\%)\end{array}$} & \multirow{2}{*}{$\begin{array}{c}\text { Late } \\
\text { stages }\end{array}$} & \multirow{2}{*}{$\begin{array}{l}\text { Percen- } \\
\text { tages (\%) }\end{array}$} \\
\hline & Examined & Infected & $\begin{array}{c}\text { Percen- } \\
\text { tages (\%) }\end{array}$ & & & & \\
\hline Puntius ticto & 100 & 71 & 71 & 26 & 36.62 & 45 & 63.38 \\
\hline Channa punctatus & 100 & 80 & 80 & 32 & 40.00 & 48 & 60.00 \\
\hline Mystus vittatus & 100 & 60 & 60 & 22 & 36.66 & 38 & 63.33 \\
\hline Colisa fasciatus & 100 & 60 & 60 & 23 & 38.33 & 37 & 61.66 \\
\hline $\begin{array}{l}\text { Anabas } \\
\text { testudineus }\end{array}$ & 100 & 60 & 51 & 16 & 31.37 & 35 & 68.62 \\
\hline Total & 500 & 51 & & 119 & & 203 & \\
\hline
\end{tabular}

Table 2. Monthly prevalence of the affected fish during August 2009-December 2010

\begin{tabular}{lccc}
\hline Month & $\begin{array}{c}\text { Total no. of fishes } \\
\text { examined }\end{array}$ & $\begin{array}{c}\text { Total no of fishes } \\
\text { infected }\end{array}$ & Prevalence (\%) \\
\hline Aug'09 & 20 & 8 & 40 \\
Sep'09 & 20 & 14 & 70 \\
Oct'09 & 20 & 15 & 75 \\
Nov'09 & 20 & 16 & 80 \\
Dec'09 & 20 & 12 & 60 \\
Jan'10 & 17 & 14 & 82.35 \\
Feb'10 & 17 & 12 & 70.58 \\
Mar'10 & 17 & 08 & 47.05 \\
April'10 & 17 & 06 & 35.29 \\
May'10 & 17 & 08 & 47.05 \\
June'10 & 17 & 09 & 52.94 \\
July'10 & 17 & 10 & 58.82 \\
Aug'10 & 17 & 15 & 88.23 \\
Sep'10 & 17 & 15 & 88.23 \\
Oct'10 & 17 & 14 & 82.35 \\
Nov'10 & 17 & 16 & 88.88 \\
Dec'10 & & 18 & 90 \\
\hline
\end{tabular}

From the Table 2, it was observed that in 2009 the highest $(80 \%)$ prevalence of infection was found in the month of November and the lowest $(40 \%)$ 
prevalence of infection was found in the month of August. In 2010, it was found that the highest $(88.88 \%)$ prevalence of infection was in the month of November and the lowest (35.29\%) prevalence was recorded in the month of April.
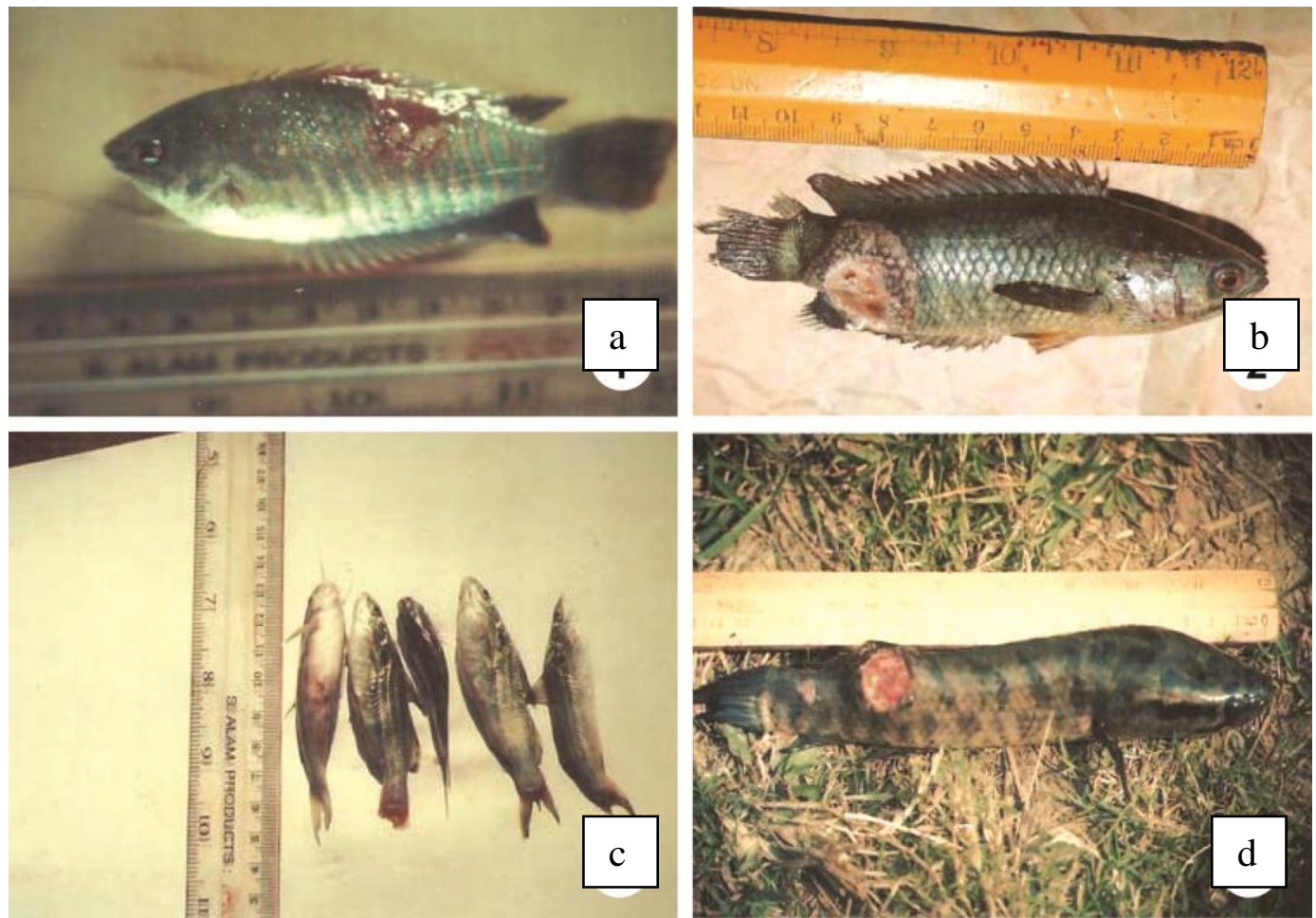

Plate 1. (a) Lesions of Colisa fasciatus that contain the fungal pathogen (late stage) (b) Deep ulceration of an Epizootic Ulcerative Syndrome(EUS) in Anabus testudinus, (c) EUS infected Mystus vittatus with eroded scales, (d) Channa punctatus shows EUS lesions on dorso- lateral side of rhe body

According to Barua (1994) EUS is first reported from the irrigation canals of the Meghna, Dhanagodha projects of Chandpur district in Bangladesh. Abdullah (1993) reported EUS in 4 districts of Bangladesh in which $71 \%$ ponds were affected. In 1990, Philips and Keddie (1990) worked on EUS in five selected spp. of fishes. In his research the overall infection rate calculated were Puntius ticto$71 \%$, Channa punctatus - 80\%, Mystus vittatus- $60 \%$, Colisa fasciatus - $60 \%$ and Anabus testudineus $-51 \%$. In the present study, the early stage infection rate were Puntius ticto $36.62 \%$, Channa punctatus 40\%, Mystus vittatus $36.66 \%$, Colisa fasciatus $38.33 \%$ and Anabus testudineus $31.37 \%$. On the other hand,late stage were Puntius ticto $63.38 \%$, Channa punctatus 60\%, Mystus vittatus 63.33\%, Colisa fasciatus $61.66 \%$ and Anabus testudineus $-68.62 \%$. The result more or less similar and the ulceration may be due to the differences in the condition of different ponds (Brit and Hastein 2008). 

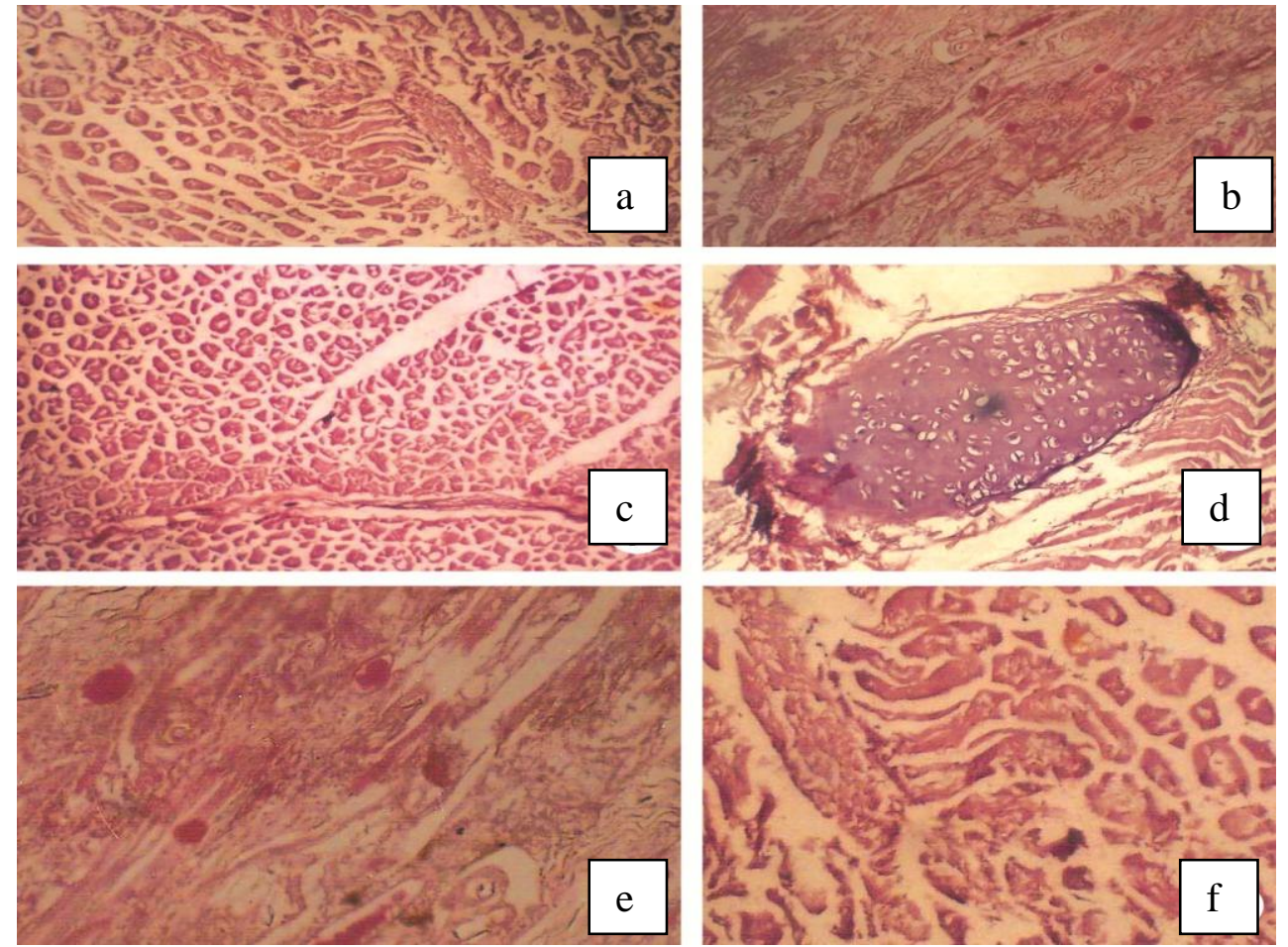

Plate 2. (a) A section through the primary lesions of lateral muscle of Puntius ticto . HES. Bar $=100 \mu(10 \times 10)$. (b) A section through the primary lesion of Puntius ticto showing eroded stratum spongiosum over which the superficial fungal hyphae are present and inflammation of subsutaneous tissues and muscle degeneration (md) PAS. Bar $=100 \mu(10 \times 10)$. (c) Giant cells and granuloma in the muscle of early stages of Channa punctatus. Bar $=100 \mu(10 \times 10)$. (d) Giant cells and granuloma in the muscle of late stages of Mystus vittatus. Bar $=100 \mu .(10 \times$ 10). (e) A section through the granulomatous tissues of Mystus vittatus showing a multinucleated giant cell engulfing a foreign body, fungal hypha. Bar $=100 \mu(10 \times$ 10). (f) A granulomatous tissues of Mystus vittatus showing a multinucleated giant cell without engulfing a foreign body, surrounded by fibrous tissue and segmented skeletal muscles. Bar $=100 \mu(10 \times 10)$.

In histopathology, the appearance of petechia as well as the spread of lesions with hyperplasic dermal layer were conspicuous at the very early stages. The subsequent muscle degeneration, followed by necrosis and formation of granulomous infiltrated by fungal hyphae was observed during the present styudy, as in the previousreports on EUS ( Lilley et al. 1992 ). The appearance of initial petechia, later haemorrhagic lesions, and multinucleated giant cells in the initial stage, followed by muscle degeneration and necrosis largely invaded by secondary fungal hyphae seemed to be a significant characteristic in most fish species. The tissues of the snakehads examined in the present study did not display any multinucleated giant cells. Miyazaki and Egusa (1973) also did not observe multinucleated giant cells within Channa maculata and C. striatus, respectively. 
The present histological study has revealed that the early stage of infection starts as a petechia with tissue haemorrhage and aggregation of melanomacrophages within muscle tissues, followed by moderate to severenecrosis with subsequent fungus and protozoan invasions. There were indications of depressed water quality as lower concentrations of anions compared to cations (hardness) implied to the disease outbreak as early stressing factor. Still a significant role of some other primary pathogen has become indispensible to breach the skin barrier (Das 1993). Limsuwan and Chinabut (1983) described a "severe chronic granulomatous mycosis" in histological sections of lesions from diseased fish in Thailand. At this time, these were thought to be due to Achlya and Saprolegnia spp. (Pichyangkura and Bodhalamik 1983), and were dismissed as secondary agents (Tonguthai 1985).

A detailed description on the histopathology of snakeheads, C. striatus experimentally infected with pathogenic Aphanomyces at different water temperatures was given by Chinabut et al. (1995). They recorded degenerative changes in all samples in the early stages of the disease, but inflammatory infiltrate is much more marked in fish kept at 26 and $31^{\circ} \mathrm{C}$. By 8 days of postinjection, extensive mycotic granulomatosis is observed in the muscle from fish maintained at 26 and $31^{\circ} \mathrm{C}$, while the fish kept at $19^{\circ} \mathrm{C}$ developed a severe invasive myonecrosis with limited macrophage response. Also showed this typical mycotic granulomatosis compared with carp when artificially infected with Aphanomyces (Wada et al. 1996). No gross signs of inflammatory responses were observed at the inoculated site of the trunk muscles of carp and it was considered histopathologically that carp had responded to the inoculated fungus more quickly and intensively than ayu. In addition, the morphometrical features of the fungal hyphae in the lesions of carp also suggested that fungal activities were suppressed by the inflammatory response (Mohan 2002).

The host fishes were divided into three length groups. These groups were categorized as: $5 \mathrm{~cm}-10 \mathrm{~cm}$ (lowest-size group), $10.1 \mathrm{~cm}-15.1 \mathrm{~cm}$ (mid-size group) and $15.1 \mathrm{~cm}-20 \mathrm{~cm}$ (highest-size group) and the lowest prevalence $(56.66 \%)$ found in $15.1 \mathrm{~cm}$. - $20.2 \mathrm{~cm}$. (highest-size group). Meanwhile the highest was $(90.90 \%)$ found in the middle size group $(10.1 \mathrm{~cm}-15 \mathrm{~cm})($ Fig 1$)$.

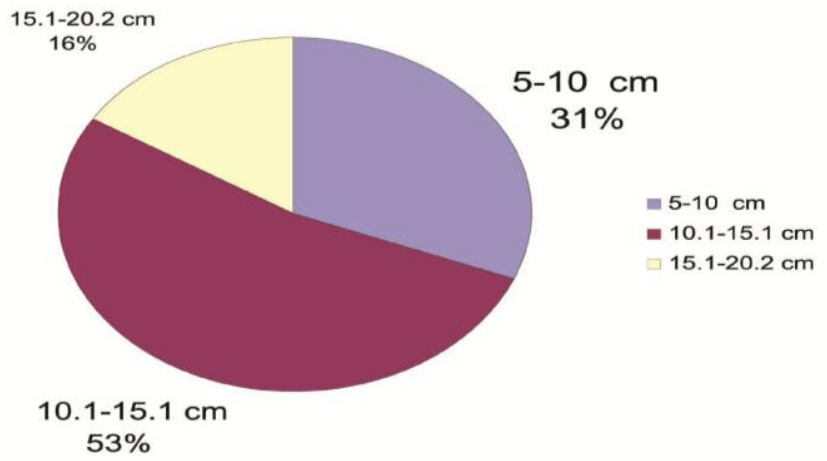

Fig 1. Overall prevalence in different length group of host fishes 
At the time of the first EUS-outbreaks in South-east Asian countries, it was perceived as a very new disease, and because of its intimate connection with the rice fields and their fishes it caused great concern because of probable dangers to both staple food crops and to human lives. The wide-spread fear of disease transmission to consumers, although unfounded, led to a drastic decrease in market demand for fish as food, including marine species which were not in fact affected by the disease (Sanaullah et al. 2001). In countries where often the only animal protein available to accompany a rice diet was derived from fish, the nutritional deficiency was obvious. It is estimated that 250 million families in the South-east Asian region depend on rice as a main crop and much of the incidental fish harvests from these paddies were an important part of the family's diet (Macintosh 1986).

Estimating an economic value for the fish losses in rural areas where little of the production even passes through rural markets was impossible, but Tonguthai (1985) estimated that direct losses to the cultured fish industry in central Thailand, is approximately US $\$ 8$ million, The average daily income of Philippine fisherman (roughly US \$ 4.00) declined to US \$ 1.50 during disease outbreaks in Laguna de Bay due to rejection of affected fish (Anon 1991). It was also concerned that repeated annual outbreaks of EUS, particularly in Lahuna de Bay, may lead to a significant decline in the natural fish population and eventually resulted in depleted stock of wild species. In Bangladesh, the epizootic ulcerative syndrome (EUS) was first noticed in 1988. And the disease has broken out in an epidemic form in the country. The epidemic created panic to the people, fish culturist as well as researchers in the country. In many areas of the country it was found that the people avoided there fish due to EUS.

However, the essential agent of EUS is an omycete fungus named by Willoughby et al. (1995) as Aphanomyces invaderis. Later, Lilley and Robert (1997) have provided further evidence that this distinct species of Aphanomyces was responsible for much of the characteristic pathology of EUS, by conducting both pathogenicity and cultural experiments. Lilley and Thompson (1997) named the fungus as Aphonomyses invadans. However the causative link between EUS and observed histopathological features needs to be further studied.

\section{LITERATURE CITED}

BARUA, G. 1994. The status of epizootic ulcerative syndrome of fish of Bangladesh. In ODA regional seminar on epizootic ulcerativesyndrome (Roberts,R.J.B. Campbell, and I.H.MacRae, eds.) Aqutic Animal Health Research Institute, Bangkok. p. 13-20.

BROWN G.G. 1978. Micro-organisms, fungi, virus inclusion bodies, and parasites. An introduction to histotechnology 1st edn. New York: Appleton-Century-Crofts.

CABLE, R.M. 1963. An illustrated laboratory manual of Parasitology.Burges Publishing Company.Minneapolis,U.S.A.pp-169 
CHINABUT, S. 1995. Epizootic Ulcerative Syndrome: The current state of knowledge. Diseases in Asian Apiculture 2.(ed. By M.Shariff, J.R. Arthur and R.P. Subasinghe).Fish Health Section, Asian Fisheries Society, Manila. p. 285-290.

CHINABUT, S. and C. LIMSUWAN. 1983. Histopathological changes in some freshwater fishes found during the disease outbreak:1982-1983. Thai Fisheries Gazette. (English Abstract).36(3):281-289.

DAS, M. K. 1993. A review of the fish disease, epizootic ulcerative syndrome in India. Environ. Ecol., 11(1): 134-145.

DRURY, R. A. B. \& E. A. WALLINGTON. 1980. Carleton's Histological Techinque, $5^{\text {th }}$ edn. Oxford University Press, Oxford.

EGUSA, S. 1992. Mycotic granulomatosis. In Infectious Diseases of Fish. Oxonian Press Pvt. Ltd., New Delhi. p.392-396.

FRERICHS, G. N ; S. D. MILLER and M. ALEXANDER. 1995. Rhabdovirus infection of ulcerated fish in Southeast Asia. In viruses of lower vertebrates (Ahne, W. and E. Kurstak, eds.) Springer- Verlag, Berlin. P. 396-440.

LILLEY, J. H; M. J. PHILLIPS and K. TONGUTHAI. 1992. A review of epizootic ulcerative syndrome ( EUS) in Asia. Aquaculture Centres in Asia-Pacific, Bangkok, Thailand. pp. 73.

MIYAZAKI, T. and S. EGUSA. 1973b. Studies on mycotic granulomatosis in freshwater fishes-IV: Mycotic granulomatosis in bluegill. Fish Pathology, 8:41-43.

MOHAN, C.V. 2002. Inflammatory response of Indian Major Carps to Aphanomyces invadans fungal pathogen of EUS. IFS Report. pp-36

ODA 1994. ODA Regional Seminar on Epizootic Ulcerative Syndrome (Roberts, R. J; B. Campbell and I. H. Macrae eds.) Aquatic Animal Health Research Institute, Bangkok. pp.170.

PHILLIPS, M. J. and H. G. KEDDIE. 1990. Regional research programme on relationships between epizootic ulcerative syndrome in fish and the environment. A report on the Second Technical Workshop. 13-26 August 1990.NACA. Bangkok.pp 116.

PICHYANGKURA, S. and V. BODHALAMIC. 1983. The study of Achyla spp. of fish disease in Ophiocephalus striatus.pp.197-205.The Symposium on Fresh Water Fish Epidemic:1982-1983.23-24 June 1983. Chulalongkorn University, Bangkok. pp128.

PRADHAN. P, K, MOHAN C.V, SHANKAR K.M, KUMAR B.M. and DEVARAJA G. 2007. Yearlings of Indian major carps resist infection against the epizootic ulcerative syndrome pathogen, Aphanomyces invadans. Current Science, 92, pp. 1430-1434.

ROBERTS, R. J, L. G. WILLOUGHBY, S. CHINABUT and K. TONGUTHAI. 1994. Mycotic Aspects of Epizootic Ulcerative Syndrome (EUS) in Asian Fishes. Journal of Fish diseases, 16:169-183.

TONGUTHAI, K. 1985. A preliminary account of ulcerative fish disease in the IndoPacific region (a comprehensive study based on Thai experiences). National Inland Fisheries Institute, Bangkok, Thailand. pp-39.

TORUD, B. and HASTEIN, T. 2008. Skin lesions in fish: causes and solutions Page. Acta Veterinaria Scandinavica .pp-1-3 
WADA, S, S.A. RHA, T. KONDOH, H. SUDA, K. HATAI and H. ISHII.1996. Histopathological comparison between ayu and carp artificially infected with Aphanomyces piscicida. Fish Pathology. 31(2): 71-80.

VIRGONA J.L .1992. Environmental factors influencing the prevalence of cutaneous ulcerative disease (red spot) in the sea mullet, Mugil cephalus L., in the Clarence River, New South Wales, Australia. Journal of Fish Diseases.pp-166-67.

(Manuscript received on 10 Mach 2014; revised on 26 June 2015) 